\title{
Viva Mulher: Constructing a cervical cancer control program in Brazil
}

\section{Marco Antonio Porto (*) and Paula Arantes Botelho Briglia Habib (*)}

\author{
(*) Universidade Federal Fluminense, Niterói. \\ m.porto@globo.com \\ $\left(^{* *}\right)$ Inovatec Program, Casa de Oswaldo Cruz, Fundação Oswaldo Cruz, Rio de Janeiro. \\ pbrigliahabib@uol.com.br
}

Dynamis

[0211-9536] 2014; $34(1): 101-123$

http://dx.doi.org/10.4321/S0211-95362014000100006
Fecha de recepción: 31 de julio de 2012

Fecha de aceptación: 17 de julio de 2013

SUMMARY: 1.-Introduction. 2.-Early initiatives. 3.-Pilot project. 4.-First campaign or first intensification phase. 5.-Consolidation phase. 6.-Second campaign or second intensification phase. 7.-Conclusion.

\begin{abstract}
Through a number of isolated initiatives that began in the 1960s, Brazil accumulated knowledge and experience that in the late 1990s culminated in the implementation of the first nationwide public health action meant to coordinate health bodies and personnel from the federal, state, and municipal administrative levels to address a chronic degenerative disease. The main goal of this article is to analyze the process of construction of this public policy for cancer control in Brazil -more specifically, organized screening for the control of cervical cancer in the form of the Viva Mulher program. Our analytical approach relies on elements from the history of public policy and from the history of institutions, combining the use of documental sources, scientific literature, and interviews with managers involved in the process under study. Our analysis endeavors to show how and to what extent this national process incorporated the experiences of local projects and responded both to pressure from the social movement and to the country's political environment. It further shows how the new context, shaped by changes in the organization of the Brazilian health system, influenced this process.
\end{abstract}

KEY WORDS: Cervical cancer, cancer control, history of cancer control in Brazil, history of disease, history of public policy.

PALABRAS CLAVE: Cáncer de cuello de útero, control del cáncer, historia del control del cáncer en Brasil, historia de la enfermedad, historia de las políticas públicas. 


\section{Introduction}

According to the José Alencar Gomes da Silva National Cancer Institute ${ }^{1}$ commonly known by its acronym, INCA, cervical cancer is the second most prevalent form of cancer among women in Brazil, associated with the deaths of some 4,986 women in 2010 and responsible for 17,540 new cases in $2012^{2}$. Estimates suggest that the Pap testing of asymptomatic women between the ages of 25 and 64, followed by treatment of detected lesions, could reduce the mortality rate by around $80 \%$. This would require a population screening program and guaranteed follow-up of cases presenting any level of positive results. In developing nations it is especially common to offer this screening test only to women who seek out health, while there is no strategy for ensuring that the most vulnerable women, namely poor women, will have the test and, if necessary, receive treatment ${ }^{3}$.

Population screening requires a structured program of regular testing of an asymptomatic population displaying greater risk factors in order to identify precursor or cancerous lesions in their initial stages. To be effective, such a program must cover at least $70 \%$ of the target population and, according to the World Health Organization (WHO), an expensive, logistically complex program is only justified if: the type of cancer is epidemiologically significant, its asymptomatic phase is long enough to allow for detection, a significant percentage of precursor lesions develop into the

1. Created in Rio de Janeiro in 1937, when the city was federal capital, the Instituto Nacional de Câncer (INCA) is Brazil's leading hospital in cancer treatment and in public policy on cancer control. The country's 1988 Constitution assigned the institute responsibility for devising a national cancer control policy, ratified under the Organic Health Law (Lei Orgânica da Saúde, no. 8080), of 1990. In October $20^{\text {th }}$ of 2011, the institute was rechristened the José Alencar Gomes da Silva National Cancer Institute in tribute to the former vice-president of Brazil, who passed away after battling the disease for nearly thirteen years. For further information on the history of the Institute, see: Teixeira, Luiz Antonio; Fonseca, Cristina Oliveira. De doença desconhecida a problema de saúde pública: o INCA e o controle de câncer no Brasil. Rio de Janeiro: Ministério da Saúde; 2007; Teixeira, Luiz Antonio; Porto, Marco; Noronha, Cláudio. O Câncer no Brasil: passado e presente. Rio de Janeiro: Outras Letras/FAPERJ; 2012.

2. Instituto Nacional de Câncer. Estimativa 2012: incidência de câncer no Brasil. Rio de Janeiro: INCA; 2011, p. 35.

3. World Health Organization. Early Detection. Cancer control: knowledge into action. WHO guide for effective programmes, module 3. Geneva: WHO Press, 2007 (updated in Nov 2009. Available from: http://www.who.int/cancer/modules/en/) 
disease, treatment is available to improve prognosis, and the screening test is accepted by patients and available at a reasonable cost $\mathrm{t}^{4}$.

Our research offers a historical analysis of the construction of the technical, scientific, and management tools indispensable to this type of initiative, while it also discusses data about the more general political framework and associated social movement in Brazil. In this regard, our article contextualizes the topic within the broader study of Brazilian public policy.

Public policy definitions and analysis models can be wide-ranging. According to Atwood and collaborators ${ }^{5}$ decision making and the implementation of public health policy is often led by crises, political considerations, and the mobilization of public opinion, triggering interdependence between medical and scientific knowledge and political and social context. Our investigation attempts to identify the actors, scenarios, and settings of the Viva Mulher program. In analyzing the program and its evolution from pilot project through subsequent campaigns, it is important to understand the conflicts and shifts between the Ministry of Health and INCA and the contribution of the social movement and the successive political and electoral contexts that, to differing degrees, played a part in building this pioneer public health policy for cancer control in Brazil.

\section{Early initiatives}

The first population screening programs for cervical cancer began in regions of the United States in the $1950 \mathrm{~s}^{6}$. In Europe, Norway created such a program in 1959, with Denmark following suit the next year. In the 1960s, a number of Nordic countries implemented similar programs and by 1966 cervical cancer screening was part of England's National Health Service ${ }^{7}$. At that time, the Pan-American Health Organization (PAHO) cited cervical cancer

\footnotetext{
4. WHO, n. 3, p. 6.

5. Atwood, Katharine; Colditz, Graham; Kawachi, Ichiro. From public health science to prevention policy: planning science in its social and political contexts. American Journal of Public Health. 1997; 87(10): 1603-1606.

6. Hakama, Matti; Chamberlain, John; Day, Nicholas; Miller, Anthony; Prorok, Philip. Evaluation of screening programs for gynecological cancer. British Journal of Cancer. 1985; 52: 669-673.

7. Löwy, Ilana. Preventive strikes: women, precancer, and prophylactic surgery. Baltimore: Johns Hopkins University Press; 2010.
} 
as an important public health problem in Latin America; after ascertaining that only limited preventive actions were being undertaken, the organization proposed that specific programs be developed to control the disease, based on mass screening using the Pap smear test ${ }^{8}$.

The 1960s saw some initiatives to apply the method in Brazil. Cervical cancer prevention efforts were then starting to move beyond doctor's offices and specialized hospitals to find their place in the public healthcare network. Established in 1956 in the city of Rio de Janeiro (former capital of Brazil), the Social Pioneers Foundation (Fundação das Pioneiras Sociais) was a philanthropic organization very active in education and health, especially in the field of chronic degenerative diseases and particularly those associated with female cancers. In the area of cervical cancer, the organization made several pertinent contributions directed at problems that still stand as central, challenging issues in the control of this kind of cancer in Brazil, especially in relation to fostering engagement with lower-class women (who find it harder both to grasp medical information and to obtain access to healthcare services) and in guaranteeing the quality of cytological tests9.

As regards the first matter, the Social Pioneers Foundation extended its activities to ten Brazilian states, creating not only specialized hospitals and, in Rio de Janeiro, a research center, but mobile hospitals as well as part of its «Health on Wheels» program, which included floating hospital units in the Amazon. As far as ensuring the reliability of the Pap smear is concerned, the first official cytopathology school was established in 1968 to provide suitable training for the technicians who had the strategic role of taking the first readings of test slides ${ }^{10}$.

In 1965, under the leadership of the Universidade Estadual de Campinas' Department of Gynecology and Obstetrics and in accordance with PAHO guidelines, a Cervical Cancer Control Program was set up in the city of Campinas, São Paulo. It was Brazil's first experience with broad-reaching, continuous ongoing action. In ten years, not only did the program reach

8. Horwitz, Abraham. Prólogo. In: Organización Panamericana de la Salud. Oficina Sanitaria Panamericana. Manual de normas y procedimientos para el control del cáncer del cuello uterino. Publicación Científica no. 248. Washington: PAHO; 1972.

9. Temperini, Rosana. A contribuição original da Fundação das Pioneiras Sociais. Palestra apresentada durante o Seminário «O Controle dos Cânceres do Colo do Útero e da Mama no Brasil - trajetória, avanços e desafios». INCA/Fiocruz. Manaus/AM, Brazil, Jun. 20-21, 2012.

10. Temperini, n. 9. 
a high number of 19,195 cytological tests per year; but on its fourth year, there was a drop in the number of lesions detected ${ }^{11}$.

Relying on the same methodology employed in Campinas, other philanthropic institutions in the state of São Paulo devised cervical cancer control programs in the late 1960s. The São Camilo Institute for the Prevention and Treatment of Gynecological Cancer (Instituto São Camilo de Prevenção e Tratamento de Câncer Ginecológico) was created in 1967, while in 1968 was inaugurated the Brazilian Institute for Studies and Research in Obstetrics and Gynecology (Instituto Brasileiro de Estudos e Pesquisas em Obstetrícia e Ginecologia, or IBEPOG) ${ }^{12}$.

By 1972, Brazil had spent eight years under a political dictatorship that took a liberal approach to economics. Grounded on this liberalism and on privatism, the predominant healthcare model enforced a merely curative approach to chronic degenerative disease, and the counterpart to the costly and not highly efficient process of equipping hospitals technologically was disregarded and preventive initiatives unattended ${ }^{13}$. That year Brazil received its first manuals of PAHO technical recommendations and the Ministry of Health drew up its National Cancer Control Plan (Plano Nacional de Controle de Câncer, or PNCC), which was launched countrywide in September 1973. Among its goals was the expansion of cervical cancer preventive actions through the Pap smear and the organization of a national network to control the disease. ${ }^{14}$

In 1975, the state of São Paulo's Center for Oncology Research Foundation (Fundação Centro de Pesquisa em Oncologia, or FCPO) introduced a statewide cervical cancer prevention program that encompassed state and municipal health posts, some private doctors' offices, and mobile testing units (buses and train cars) ${ }^{15}$.

By the mid-1980s, Brazil's healthcare model for cervical cancer had only allowed for prevention and early detection measures in the form of isolated, sporadic, non-nationwide initiatives carried out by certain institu-

11. Pinotti, José Aristodemo; Zeferino, Luiz Carlos. Programa de controle de câncer cérvico-uterino. Campinas: Editora da Unicamp, Série Saúde da Mulher; 1987.

12. Teixeira; Porto; Noronha, n. 1, p. 103.

13. Silva Jr., Aluísio Gomes da. Modelos Tecnoassistenciais em Saúde. Rio de Janeiro: HUCITEC; 1998.

14. Teixeira; Porto; Noronha, n. 1, p. 100-102.

15. Capucci, Fatima. Filosofia Sampaio Góes: Instituto Brasileiro de Controle do Câncer - IBCC 35 anos. São Paulo: Editora Activa Comunicação; 2003. 
tions - generally philanthropic ones - or by health departments, usually municipal. In 1985, it was estimated that the cytological test for cervical cancer had reached only $2 \%$ of Brazil's female population ${ }^{16}$.

In 1984, against a backdrop of political re-democratization and the re-emergence of the social movement, the Integral Program for Women's Healthcare (Programa de Atenção Integral à Saúde da Mulher, or PAISM) was created, which included cervical and uterine cancer prevention and control. As of 1985-86, the National Council on Women's Rights (Conselho Nacional de Direitos da Mulher, or CNDM) and the National Institute of Medical Assistance (Instituto Nacional de Assistência Médica da Previdência Social, or INAMPS) started working together in order to solidify PAISM at a national level. In 1986, the National Division of Chronic Degenerative Diseases' National Cancer Campaign (Campanha Nacional de Combate ao Câncer) put together a working group entrusted with elaborating a new strategy for dealing with cancer in Brazil ${ }^{17}$.

In 1987, on the eve of formalizing the principles of the Public Health Reform contained in the new Brazilian Constitution (issued in 1988) ${ }^{18}$ the Pro-Onco Oncology Program was created; its projects included the «Expansion of the Prevention and Control of Cervical and Uterine Cancer» ${ }^{19}$. In 1988, Pro-Onco held a conference entitled «Consensus on the Periodicity and Age Range for Preventive Testing for Cervical and Uterine Cancer», attended by Brazil's top experts in the control of these cancers, members of the PAISM and representatives of women's movements. Its by-product was a series of technical recommendations that became part of the approach

16. Ministério da Saúde/Ministério da Previdência e Assistência Social. Projeto de Expansão da Prevenção e Controle do Câncer Cérvico-Uterino - Quinquênio 1988-1992. Rio de Janeiro; 1988.

17. Teixeira; Porto; Noronha, n. 1, p. 104-106.

18. Brazil's Public Health Reform Movement got underway in the late 1970s, culminating in 1986 with the Eighth National Health Conference. Its general lines defended health as a right of all citizens and a duty of the State, with universal access to all goods and services that promote and restore health. Out of this movement came the main guidelines of the 1988 Constitution's chapter on health and also of the Unified Health System (Sistema Único de Saúde), created in 1990. Escorel, Sarah; Nascimento, Dilene Raimundo; Edler, Flávio Coelho. As origens da reforma sanitária e do SUS. In: Lima, Nísia Trindade; Gerschman, Silvia; Edler, Flavio Coelho; Manuel Suárez, Julio. Saúde e democracia: história e perspectivas do SUS. Rio de Janeiro: FIOCRUZ; 2005, p. 59-81.

19. Ministério da Saúde/Ministério da Previdência e Assistência Social. Projeto de Expansão da Prevenção e Controle do Câncer Cérvico-Uterino - Quinquênio 1988-1992. Rio de Janeiro, 1988. 
endorsed by the Ministry of Health - for example, a target age range of 25 to 60 and a three-year screening interval after two negative results ${ }^{20}$.

By the end of the 1980s, Brazilian women were enjoying greater citizenship status and much had been achieved in the production of scientific and epidemiological knowledge. Combined with various local and national experiences, this stimulated the demand for cervical cancer to be addressed in an organized fashion and at a nationwide level. In addition, Brazilian health services had undergone a structural change. In 1988, the new Constitution had proclaimed health a «right for all and a duty of the State ${ }^{21}$ and in 1990, the Unified Health System (Sistema Único de Saúde, or SUS) was created under Law no. 8080, laying the instrumental basis for ongoing actualization of this newly attained right. This new environment promoted the changes observed in the control of cervical cancer during the course of the 1990s.

\section{Pilot project}

The aforementioned context aside, Brazil had no prior experience implementing a national program for secondary prevention of any type of disease prior to the 1990s. Moreover, Brazil's sharp regional differences in terms of socioeconomics, geography, climate, and epidemiology tend to discourage attempts to set up a nationwide program with any singularly defined, rigid features.

With these obstacles in mind, and with the goal of collecting data on the Brazilian healthcare networks in order to help develop a broader strategy, INCA announced the foundations of the Viva Mulher pilot program on the 27th November 1996, during the National Day Against Cancer (Dia Nacional de Combate ao Câncer). In 1997, with the aid of Canada's Cancer Care International / Ontario Foundation - which had a large experience in planning organized screening programs, INCA began setting up this project

20. Abreu, Evaldo. Pro-Onco 10 anos. Revista brasileira de cancerologia. 1997; 43 (4): 237-238.

21. Article 196: «Health is a right of all and a duty of the State and shall be guaranteed by means of social and economic policies aimed at reducing the risk of illness and other hazards and at the universal and equal access to actions and services for its promotion, protection, and recovery». Constitution of the Federative Republic of Brazil. Text enacted on October 05, 1988, Section II - On health, page 33. Available from: http://www.senado.gov.br/legislacao/ const/con1988/CON1988_05.10.1988/CON1988.pdf (accessed May 31, 2012). 
in municipalities of Brazil. Hubs were created in Curitiba, capital of Paraná, in January; in March, they reached Brasilia and smaller cities in the Federal District (Tabatinga, Ceilândia, and Samambaia); Recife, Pernambuco; and districts in Rio de Janeiro's West Side (Campo Grande, Bangu, and Santa Cruz); in April, Belém, Pará; and in January 1998, the state of Sergipe - thus spreading services over five of the country's macro-regions.

Viva Mulher sought to lower the incidence of the disease and its mortality rate by expanding access to cytopathology testing, first and foremost for women at greater risk, and also by guaranteeing adequate treatment of the disease and its precursor lesions in $100 \%$ of cases. The program's target population was women aged 35 to 49; and a total of 124,440 women received care, of which $3.7 \%$ presented abnormal results and $5.7 \%$ were tested for the first time ever (ranging from 1.4\% in Sergipe to $9.7 \%$ in Belém) ${ }^{22}$.

The Ministry of Health provided direct funding for pilot project phases through both INCA and the Ary Frauzino Foundation (FAF) ${ }^{23}$, which facilitated management and expedited actual implementation of initiatives. In technical terms, it was vital that the project spawn intermediary products with a view to the future structuring of a country-wide program. Generally speaking, Viva Mulher's main contributions were the establishment of a model of decentralized action, the standardization of all stages of procedures (including adoption of the nomenclature that since 1993 had been endorsed by the Ministry of Health and by the Brazilian Society of Cytopathology), geographic expansion, and the definition of the recommended periodicity for Pap smears ${ }^{24}$.

By conducting qualitative surveys among health professionals and the female populations in question, the pilot project sought to devise communication strategies that would overcome cultural and regional resistance. It enjoyed the support of the Universidade Federal do Rio de Janeiro (UFRJ) in preparing communication materials tailored to these groups. One of its greatest successes was probably the incorporation of the

22. Ministério da Saúde. Viva Mulher - Relatório Novembro de 2000 - metas cumpridas e novas perspectivas. Rio de Janeiro: INCA; 2000.

23. The Ary Frauzino Foundation for Cancer Research and Control (Fundação Ary Frauzino para Pesquisa e Controle do (âncer) was created in 1991 by Marcos Moraes, then director of INCA, and three other physicians: Magda Côrtes Rodrigues Rezende, Jaime Brandão de Marsillac, and Ulpio Paulo de Miranda. FAF's main purpose is to provide INCA with administrative support. Its name was changed in 2010 to the Cancer Foundation (Fundação do Câncer).

24. Abreu, n. 20. 
technique known as «See and Treat» («Ver e Tratar»), under which women with precursor lesions of cancer were treated with high-frequency surgery ${ }^{25}$.

At the same time, the pilot project also revealed some critical obstacles that would have to be addressed if a national program were to be launched. It was noted, for example, that guaranteeing the quality of test results would depend on the monitoring of external laboratories; software would have to be more user-friendly and, primarily, compatible with SUS systems; funding mechanisms would have to be found for ambulatory procedures; and managers would have to be recruited for a task of this magnitude ${ }^{26}$.

However, in August 1998, before the pilot project was concluded and its results analyzed, the Ministry of Health took over responsibility for the control of cervical cancer in Brazil, through a broad national campaign that became known as the «intensification phase» - a move that constituted a kind of surreptitious intrusion. Perhaps the euphemism «intensification phase» was meant to suggest that this action had been planned all along and that a new phase had already been in the making, aimed at geographic expansion of the Viva Mulher pilot project. If such were the case, the initiative should not have come at a moment when most of the pilot activities had been underway for a little more than one year and, in the case of the state of Sergipe (the last to implement the Viva Mulher program), for only seven months.

The Ministry of Health presented the proposal for the national campaign to the Intersectoral Commission on Women's Health (Comissão Intersetorial de Saúde da Mulher, or CISMU), an advisory board to the National Health Council (Conselho Nacional de Saúde, or CNS). Arguments against the idea were raised during subsequent discussions. There was concern that ground might be lost in the effort to enforce a paradigm of integral health care for women, since the Ministry would go back to working towards the solution of one specific problem, as well as a fear that the SUS would be unable to handle the expected large influx of women, who would then find themselves without treatment ${ }^{27}$. Among the matters discussed at its August 1998 meeting, the CNS expressed its apprehension about the

\footnotetext{
25. Ministério de Saúde, n. 22, p. 9.

26. Abreu, n. 20.

27. Lago, Tania Di Giacomo de. Políticas Nacionais de Rastreamento do Câncer de colo uterino no Brasil - Análise do período 1998 a 2002. Campinas: Universidade Estadual de Campinas; 2004.
} 
infrastructure that the Ministry of Health would be relying on to conduct the national campaign ${ }^{28}$.

At that time, the Seventeenth International Cancer Congress was taking place in Brazil, under the sponsorship of the Union Internationale Contre le Cancer (UICC), the main worldwide NGO devoted to the fight against cancer (founded in 1933), at present with 400 member organizations from 120 countries. It was not only the leadership of INCA - the institute that coordinated the pilot project- but also the majority of the experts attending the congress who felt the Brazilian government had precipitated itself and who condemned the ministerial decision. On August 29, 1998, the newspaper Folha de São Paulo ${ }^{29}$ published the opinions from Brazilian specialists in health system and members of international agencies for cancer control who were against the implementation of the national campaign. Anthony Miller, PAHO consultant and member of the International Agency for Cancer Research (IARC), stated:

«This should have been done in stages, and with smaller groups, as a continuation of Viva Mulher. We're very concerned about this mass campaign, undertaken without our recommendation. Sometimes governments do things like this» ${ }^{30}$.

28. In her expert statement about the National Program to Fight Cervical Cancer (Programa Nacional de Combate ao (âncer do Colo Uterino), board member Zenite Freitas said that the program's goal was to improve Brazilian women's quality of life by reducing morbidity and mortality rates from cervical and uterine cancer through early detection with the Pap smear followed by suitable treatment of the cancer and of precursor lesions. However, she also admitted to some shortcomings: 1. the lack of a follow-up structure; 2 . the program's non-continuous nature; 3 . a paucity of human resources; 4 . the absence of public-private relations; 5 . the absence of any explicit quality control; 6 . the non-involvement of states and municipalities (a SUS principle); 7. the excluding, selective nature of the program's focus on a specific age range; 8 . ethical concerns, given the risk of detecting the disease without affording the prospect of treatment and follow-up. Ministério da Saúde. Atas do Conselho Nacional de Saúde [article in Internet]. 1998 [accessed Nov 2011]: lines 442-451. Available from: http:// conselho.saude.gov.br/atas/atas_00.htm.

29. Founded on February 19, 1921, the Folha de S. Paulo is one of the most influential newspapers in Brazil and the second largest in circulation, according to data from the Instituto Verificador de Circulação (IVC). It is published in the city of São Paulo by Grupo Folha. The Folha de São Paulo at first supported the 1964 military takeover and subsequent dictatorship, but in the mid-1970s the paper began defending a return to democracy and was the first in the Brazilian media to embrace the struggle for direct elections and cover the «Elections Now» movement.

30. Escóssia, Fernanda da; Martins, Lucia. Consultores criticam campanha do cancer. Folha de São Paulo [article in Internet]. 29 Aug 1998, p. 3. [accessed Nov 2011]. Available from: http:// 
Denny Depetrillo - Head of Surgical Oncology at Princess Margaret Hospital, Coordinator of the Surgical Oncology Network for Cancer Care Ontario and Vice President of Professional Affairs for Cancer Care International- went further:

«Things were rushed, and I am concerned about the shortage of properly trained personnel to perform the tests. I know that the government has the money. But I think there'll be trouble with infrastructure» ${ }^{31}$.

Hildoberto Carneiro de Oliveira, professor from the Universidade do Estado do Rio de Janeiro (UERJ) and former chairman of the Brazilian Federation of Societies of Gynecology and Obstetrics (Febrasgo), was of the same opinion: «They rushed to launch the campaign - possibly for political reasons» ${ }^{32}$.

In addition to these opinions from specialists, the newspaper wrote that sources said «the ministry also had allegedly received a PAHO report criticizing the launching of the campaign». "The ministry denied this information», Folha stated further on in the same article ${ }^{33}$.

Contested by the technical group responsible for coordination of Viva Mulher and by the leadership of INCA itself - all in frank disagreement with him - and also finding himself facing opposition from both Brazilian and foreign experts, the Health Minister spoke to Folha:

«Health Minister José Serra says he considers the criticisms of experts "the poppycock of people on the outside". According to him, the prevention campaign will only help and will take the problem [of cervical cancer] to women: "This can in no way hurt". The ministry said it would "be entirely able to" finalize all stages of the prevention program. "This is a program with a beginning, a middle - and it only has no end because we intend to continue it", says Paulo Kalume, with the National Program to Fight Cervical Cancer (Programa Nacional de Combate ao Câncer do Colo Uterino). According to

acervo.folha.com.br/resultados?q=viva+mulher\&site=fsp\&periodo=acervo\&x=14\&y=15. The newspaper Folha de São Paulo does not offer a direct link to the news, but to the electronic search system.

31. Escóssia; Martins, n. 30.

32. Escóssia; Martins, n. 30.

33. Escóssia; Martins, n. 30. 
him, "the ministry has mapped out a number of regions in the country for organizing the campaign ${ }^{34}$.

These blatant disagreements over the campaign execution were cut short by a show of strength on the part of the Health Minister, who, a few days later, dismissed the director of INCA, leading to the resignation of his appointed staff. In counterpart - and the misgivings cited earlier notwithstanding - the ministry received the support of the National Health Council ${ }^{35}$.

\section{First campaign or first intensification phase}

The Health Ministry's intervention in the Viva Mulher pilot project does not appear to have stemmed from any criticism about the work INCA had done on the project up until then or from any technical discrepancies. As suggested earlier, the reasons behind it seem instead related to matters of a more general political nature and to a logic lying outside the field of cancer control.

In September 1995, the United Nations had held the Fourth World Conference on Women: Action for Equality, Development, and Peace, in Beijing, China. Present at the event were 189 governments and over 5,000 representatives of 2,100 NGOs from around the world. For two years, the women's movement in Brazil had worked with over 800 women's groups in preparation for the event, and the country proved an active participant. During the preparation phase, the Brazilian government drafted and submitted a paper to the UN entitled «General Report about the Woman in Brazilian Society»(«Relatório Geral Sobre a Mulher na Sociedade Brasileira»); it

34. É bobagem', diz ministro Serra. Folha de São Paulo. [Article in Internet]. 29 Aug 1998, p. 3 [Accessed Nov. 2011]. Available from: http://acervo.folha.com.br/resultados?q=viva+mulher\&site $=f$ sp\&periodo $=$ acervo\& $x=14 \& y=15$.

35. CNS Resolution no. 285: «The Council shall support the development of the National Program to Fight Cervical Cancer» and requests that the «Ministry of Health continue to submit to the CNS, through the CISMU, information about the development of the Program». Informes e Notícias, Conselho Nacional de Saúde apóia mobilização nacional para prevenção do câncer de colo de útero. [Article in Internet] Jul./Aug. 1998 [Accessed Jun.2012]. Available from: http://www.datasus.gov.br/conselho/informes/240898/cancerutero.html. 
also sent a 25 member delegation to the event itself, led by the First Lady, Ruth Cardoso ${ }^{36}$.

The main topics addressed in Beijing were: advances in human rights for women; women and poverty; women and decision-making; female children; and violence against women. There were two health priorities: the prevention and promptly treatment of gynecological cancers, and family planning. The head of the Brazilian delegation committed the nation to working to change the reality of cervical cancer. The personal and intense involvement of the wife of the President of Brazil strengthened the links between the federal government and the women's movement, fueling an expectation for greater female participation in public policy making in Brazil, including the health area ${ }^{37}$.

In the worlds of Nelson Cardoso de Almeida, an important manager during Viva Mulher program:

«The Viva Mulher program was a response to demands by former First Lady Ruth Cardoso, with former INCA director Marcos Moraes. She wanted a strong cervical cancer control program because she had taken on this commitment at the International Women's Conference in China. She herself was under pressure from the organized women's movement, and passed this pressure along upon her return to Brazil. The project was born, but not, it doesn't seem to me, at the pace the government had hoped for. In a nation this size, it's very hard to lay a solid foundation across the whole country. I think that at some point, [there came] the realization that the natural course of the Viva Mulher program, the way it was being conducted, would take longer than expected. So it was decided to wage a major national initiative to mobilize women and municipal and state governments to join in the process» ${ }^{38}$.

36. Conselho Nacional de Direitos da Mulher. IV Conferência Mundial Sobre a Mulher: Ação para Igualdade, Desenvolvimento e Paz (Beijing, 1995). Rio de Janeiro: Fiocruz; 1996; Lago, n. 27, p. 29.

37. Conselho Nacional de Direitos da Mulher, n. 36, p. 29.

38. The authors participated in interviews or had access to interviews with managers involved in establishing Viva Mulher, to wit: Luiz Claudio Thuler (interviewed on 9 Oct 2010); Nelson Cardoso de Almeida (interviewed on 5 May 2011); Lucília Zardo (interviewed on 20 May 2011); and Tereza Feitosa (interviewed on 26 Oct 2011). Acervo de Depoimentos do projeto «História do Câncer - atores, cenários e políticas públicas»: Available from: www.historiadocancer.coc.fiocruz.br. Almeida, Nelson Cardoso. Acervo de Depoimentos do projeto «História do Câncer - atores, cenários e políticas públicas». Rio de Janeiro: Fiocruz/Casa de Oswaldo Cruz/DEPES. Interview given on 5 May 2011 to researchers Letícia Pumar and Paula Habib. 
In 1998 - the year Brazil's president was on the campaign trail, taking advantage of the new right to re-election within the executive branch that had been granted under a Constitutional amendment - the Ministry of Health apparently decided to use the opportunity to respond loud and clear to the pledge made in Beijing. This decision - besides eliciting the reaction by foreign experts mentioned earlier- also generated controversy among Brazilian health professionals and academics, especially in the public health field. All warned about the weak efficacy of temporary actions and the need to create an ongoing, standardized program to control cervical cancer in Brazil ${ }^{39}$.

Despite these many criticisms and question marks, from August 18 to September 30, 1998, the intensification phase of Viva Mulher got underway, now under the coordination of the Ministry of Health's Department of Health Policy, with technical assistance provided by a national committee comprising representatives of diverse areas within the Ministry itself as well as from the ministries of the Navy, Army, and Air Force, along with representatives from fifteen public or private institutions, such as the Catholic Church's Pastoral da Criança (Children's Ministry), the National Councils of Municipal and State Health Departments, and some scientific societies. It should be taken into account that the SUS was only ten years old at the time and that this was the country's first major nationwide experience in mobilizing public institutions and civil society ${ }^{40}$.

According to a Health Ministry's report, $97.9 \%$ of Brazilian municipalities (i.e., 5,389 of them) took part in the intensification phase and 3,177,740 Pap smears were done, of which $72.1 \%$ represented women from the target population. In addition to repeating the pilot project's successful strategies, and in view of its national character, this campaign (or intensification phase) sought to enact other initiatives as well, yielding positive results for the overall process ${ }^{41}$. Among them were the implementation of a specific electronic system for monitoring activities (Siscolo) and the consolidation of the decentralization process initiated under the pilot project, which included expansion of laboratory coverage for slide reading, the establishment of 244 centers around the country where high-frequency surgery was available, and the formation of a regional tertiary healthcare network. Considering

39. Ministério da Saúde, n. 22, p. 16.

40. Ministério da Saúde, n. 22, p. 38.

41. Ministério da Saúde, n. 22, p. 45-47. 
the main factors behind disease vulnerability, the intensification phase met important goals: $38.6 \%$ of examined women had never had a Pap smear and $72.1 \%$ of the tests (according to Siscolo records only) involved women in the target age group ${ }^{42}$.

The slogan «Remind someone you care about» («Lembre alguém que você queira bem») became the main message of a large-scale publicity campaign, encompassing television and radio ads, billboards, posters, and flyers as well as publicity stunts in major cities, like giant pink ribbons ${ }^{43}$ wrapped around monuments and public buildings. The campaign let Brazilian women know that they had a major commitment in August and September of that year: to have a cervical cancer prevention test.

A number of operational glitches kept the campaign from running smoothly and impeded the achievement of the planned objectives. The establishment of the electronic Siscolo system was disorganized, leading to inconsistencies in the inclusion of data by laboratories. Two weeks after the activities commenced, the proposal to focus on the 35-49 age range had to be tabled under heavy and spontaneous pressure from women seeking Pap smears at health posts:

«Two weeks into the campaign, the guideline had to be thrown out and the test opened up to everyone, because women were out on the streets demonstrating. During the second campaign [to be addressed next in this article], we expanded the age range to 25 to 59 and advised the states and municipalities that we visited not to deny women the test $»^{44}$.

Since the health system was not prepared for an initiative of this magnitude, many women who responded to the campaign could not get tested, one reason being a shortage of doctors. An attempt was made to solve this problem by extending the campaign for 15 more days ${ }^{45}$.

The biggest problems, however, had to do with reading the slides and dealing with women whose results were positive. It was not unusual, for

\footnotetext{
42. Ministério da Saúde, n. 22, p. 48-50.

43. This pink symbol had no relationship with the international campaign dedicated to breast cancer, known as «Pink Ribbon».

44. Thuler, Luiz Cláudio. Acervo de Depoimentos do projeto «História do Câncer - atores, cenários e políticas públicas». Rio de Janeiro: Fiocruz/Casa de Oswaldo Cruz/DEPES; Interview given on 9 October 2010 to researchers Letícia Pumar and Marco Antonio Porto.

45. Thuler, n. 44.
} 
instance, that results were lost in the mail; that addresses were incomplete or incorrect in at least 30\% of the cases, which hampering the localization of the woman and their subsequent follow-up. In addition the quality control module for the tests was not ready in time for the campaign and, surprisingly, the number of tests completed corresponded to only one-third of those recorded in the Siscolo system, limiting any quantitative data analysis ${ }^{46}$.

In the state of Acre, located in the North of Brazil, six months after the campaign had ended, a box was found with over one thousand slides that had never been read. The material was forwarded to INCA's laboratory and the results returned to Acre's Department of Health. Nearly one year had passed since testing, and it was extremely difficult to locate the women and give them their results:

"Women would go to a health centre and when they got there, there wouldn't be any doctor to see them. She'd have a test done and wouldn't get the results. Six months later, for example, like in the state of Acre, we recovered a box of slides from the first campaign, a box with a thousand and some slides. Not a single one had been read. The tests had been done but the slides had never been stained. They came here to SITEC and were stained here, examined here, and the results returned to the women. The trouble is that one year later, it gets really hard to find a woman to give her the results» ${ }^{47}$.

In conclusion, the state of unpreparedness on the part of the health network, in combination with the operational complexity of a campaign that had to be completed in a month and a half, put at serious risk a contingent of 12,125 women with positive diagnoses for high-grade precursor lesions or for cancer, and a strategy had to be devised for handling these cases. The Ministry of Health swiftly responded by giving the coordination of the cervical cancer control program back to the INCA, together with the responsibility for locating and providing treatment to the thousands of affected women.

According to the majority of public health managers and social leaders interviewed, the most successful facet of this phase was the far-reaching social communication plan, devoted to publicizing the campaign and to mobilizing women to take the test. The strategy was to get women to

\footnotetext{
46. Instituto Nacional de Câncer. Programa Nacional de Controle de Câncer do Colo do Útero Evolução Histórica. Rio de Janeiro: INCA; 2000, p. 21-26.

47. Thuler, n. 44.
} 
tie a pink ribbon around their wrists, a gesture associated with trying to remember something like an important fact or date.

\section{Consolidation phase}

In November 1998, under new direction, the INCA was charged by the Ministry of Health with solving the issue of what to do about women whose results had been positive during the national campaign. But the institute was also unprepared to handle this sudden challenge, which called for considerable effort on the part of the staff at the INCA's prevention and control sector, known as CONPREV (Coordenação de Prevenção e Vigilância). The team worked under great pressure, with the Health Ministry demanding results as it in turn was admonished about its responsibility to the women mobilized by the campaign. At the end, and after almost one year of intense investigations and close communications with state and municipal health departments the result was perhaps inadequate given the matter's serious nature, but it was equally surprising, considering the conditions under which the work was done: $83 \%$ of women presenting positive results were located and treated ${ }^{48}$.

Starting in April 1999, the INCA tried to ensure the continuity of its first organizational accomplishments and to make further progress with the structure of Viva Mulher, incorporating the experience gained in the national campaign. This included strengthening the program's geopolitical base by signing agreements with state-level departments, adjusting protocols for follow-up of women presenting positive results, expanding human resource training at all levels of the service network, increasing the number of cytopathology laboratories and enforcing proper use of Siscolo, refining and expanding high-frequency surgery centers, and, in terms of more general national management, using the rate of cytopathology testing for cervical cancer among the female population as a measure of primary health care at the level of Brazilian municipalities ${ }^{49}$.

\footnotetext{
48. Ministério da Saúde. Viva Mulher - Câncer do colo do útero: informações técnico-gerenciais e ações desenvolvidas. Rio de Janeiro: INCA; 2002.

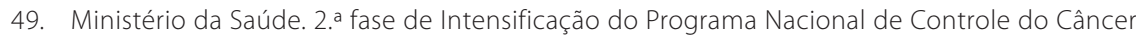
do Colo do Útero. Brasília: Centro de Documentação; 2001.
} 
A vital element for continuation of the program was the preservation of financing from the Fund for Strategic Actions and for Compensation (Fundo de Ações Estratégicas e de Compensação, or FAEC), which had been paying for exams; for each state and municipality, this funding was estimated to cover the equivalent to annual screening of $30 \%$ of resident women between the ages of 25 and $60^{50}$.

\section{Second campaign or second intensification phase}

After re-assuming management of cervical cancer control actions, and also after resolving the problems caused by the 1998 national campaign, the INCA outlined a strategy centered around two general concerns: preserving the structure mounted during the first intensification phase and investing efforts in the consolidation of a network of communications, knowledge, and services robust enough to underpin regular initiatives by the Viva Mulher program. This endeavor continued until 2001, when the Ministry of Health called for a new campaign, this time to be managed by the INCA in conjunction with an Executive Committee representing various of the ministry's technical sectors ${ }^{51}$, an idea that proved operationally clumsy given the lack of any real working relationship between the institute and ministerial sectors.

The second intensification phase not only could count on human resources and a material structure that had been gradually assembled since the pilot project got underway in January 1997; it also began its preparations much earlier than the first phase, allowing the INCA staff to work with health departments in more populous states and municipalities to improve their level of organization. The proposal for the new national campaign was first submitted to the Tripartite Inter-managerial Commission (Comissão Intergestores Tripartite) on May 17 and June 20 and then to state coordinators of the Viva Mulher program and representatives of the Council of Municipal Health Departments (Conselho dos Secretários Municipais de Saúde) on July 11 and 12 in Brasilia and on July 17 and 18 in Rio de Janeiro ${ }^{52}$.

\footnotetext{
50. Ministério da Saúde, n. 48.

51. Portaria no. 1102/Gabinete do Ministro, July 30, 2001.

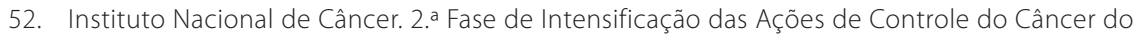
Colo do Útero. Rio de Janeiro: INCA; 2001.
} 
Once again, the proposed target population was women in the 35-49 age bracket who had never had a Pap smear test or who had not had one in the past three years; the goal was to accelerate coverage of the Brazilian female population and to reach women in the highest risk group age-wise. There was an unprecedented move to coordinate work with the National Indian Foundation (FUNAI), who took on the task of conducting tests among indigenous women and providing health departments with results ${ }^{53}$.

To attain the goal of testing 2.5 million women, and to bypass some of the hurdles encountered in the first campaign, the healthcare network was sent enough material to make the Pap smear test to respond to a $30 \%$ increase in the demand. This decision proved very successful as over 3.8 million women ended up being tested. Responding not only to women's natural interest in getting tested even if outside the target age limits, the campaign coordinators expanded the age range to 25-59 and told states and municipalities they should not deny a Pap smear to anyone requesting one ${ }^{54}$.

The Health Ministry's Social Communication Office (Assessoria de Comunicação Social) drew up flyers and posters and sent this material to health departments in advance in order to help mobilize women. Criticisms were lodged about the material, especially the particular female model chosen to illustrate it, as she looked nothing like the population targeted by the campaign. Radio and TV ads also ran on a number of popular programs, featuring the new Health Minister (the former Minister had stepped down to run for president) ${ }^{55}$.

To manage the campaign, the INCA put in place a logistics system that accompanied activities, centralized in a situation room that was in permanent contact with health department's heads through telephone and videoconferencing via satellite. Still, there were sporadic problems, such as in the city of São Gonçalo, Rio de Janeiro, where health posts failed to open on time, and in the city of Rio de Janeiro itself, which was grappling with an epidemic of dengue fever and moved the campaign to start on May 7 until June 6 of 2002:

"At the time of the second campaign, we set up a "situation room" at INCA, with people at CONPREV with their ears to the telephone. People had

53. Ministério da Saúde, n. 48, p. 45-48.

54. Ministério da Saúde, n. 49, p. 12.

55. Ministério da Saúde, n. 48, p. 58-59. 
their ears glued to the phone all day, using those headset things. The person would spend all day just taking calls from municipalities and states. We did videoconferencing via [satellite], for municipalities where there was a signal. [...] We tried to get as close as possible to those who were actually going to carry out the work» ${ }^{56}$.

There were no new campaigns after that. Starting in 2005, the Viva Mulher program began emphasizing the formation of the Oncological Care Network (Rede de Atenção Oncológica) ${ }^{57}$ by providing technical assistance to health departments, upgrading Siscolo technologically (DATASUS), and defining indicators for monitoring its initiatives ${ }^{58}$.

\section{Conclusion}

Like other chronic diseases, cancer requires complex and continuous health action involving different levels of the health system. Although cervical cancer has long been a public health problem in Brazil, a number of factors delayed the adoption of a proper program for addressing it. In more general terms, the main hindrance was the health model in place prior to the enactment of the 1988 Constitution and the 1990 creation of the Unified Health System

56. Thuler, n. 44.

57. Administrative Ruling (Portaria) GM no. 2439, of December 18, 2005, established the National Oncological Care Policy (Política Nacional de Atenção Oncológica), which recognized cancer as a public health problem and determined that actions to control the disease were undertaken within the sphere of an Oncological Care Network, with the participation of the federal government and state and municipal health departments. One important guideline indicated that all municipal and state health plans had to include a cervical cancer control plan (Ministério da Saúde. Portaria n. $2.439 / G M$. Institui a Política Nacional de Atenção Oncológica: promoção, prevenção, diagnóstico, tratamento, reabilitação e cuidados paliativos, a ser implantada em todas as unidades federadas, respeitadas as competências das três esferas de gestão. Diário Oficial da República Federativa do Brasil. Brasilia, DF, no. 76, seção 1, pp. 80-81, Dec., 2005). Later, the «Health Pact» (Ministério da Saúde. Portaria n. 399/GM. Divulga o Pacto pela Saúde 2006 - Consolidação do SUS e aprova as Diretrizes Operacionais do Referido Pacto. Diário Oficial da República Federativa do Brasil. Poder Executivo, Seção 1, p. 43. Brasilia, DF, Feb., 2006); the National Basic Care Policy (Ministério da Saúde. Secretaria de Atenção à Saúde. Departamento de Atenção Básica. Política Nacional de Atenção Básica. Brasilia: Ministério da Saúde, 2006); and the «More Health: Everyone's Right - 2008-2011» program (Ministério da Saúde. Programa Mais-Saúde - Direito de Todos: 2008-2011. [Série C. Projetos, Programas e Relatórios], 2으 ed. Brasilia, DF, 2008) also placed priority on measures to control this type of cancer.

58. Ministério da Saúde, n. 49, p. 65-70. 
(SUS), which granted universal access of the population to a network of health services with different levels of complexity. In this scenario, only a small portion of the population - government workers and those employed in the formal market- had access to health services at different levels of complexity. The Ministry of Health, still heedless of the epidemiological changes in course in Brazil, took charge of controlling the so-called «major endemic diseases», which comprised an array of infectious illnesses that did not include any chronic degenerative disease, like cancer.

Furthermore, the country's technical and assistance model directed funds and efforts almost exclusively toward the incorporation of heavy technology, especially in the hospital environment and in the practice of «super specialties» ${ }^{59}$. In such a context, issues like health promotion, prevention measures, and early detection of cancer received little objective support. The absence of any commitment to basic public health action was also made manifest in the priorities chosen for addressing disease problems and in the lack of any conceptual link between health and development.

Nine years after health care became a right under Brazil's 1988 Constitution, and seven years after the INCA's foundation, the institute launched a pilot project aimed at future construction of a cervical cancer control program in Brazil. Despite the urgent need to address the second most common form of cancer among women in Brazil, the lack of basic structural conditions combined with inexperience in setting up nationwide programs led to the adoption of a progressive strategy, where knowledge and experience could be acquired while working alongside state and municipal health departments. In short, it would be necessary to devise and bring to maturity a coordinated multi-stage program that could have a significant impact on the incidence and mortality rates for this kind of cancer.

In focusing on a number of Brazil's macro-regions, the Viva Mulher pilot project strove to integrate several social and cultural elements from the target population (including gender issues) with technical, scientific, and knowledge management. As one might expect, the pilot project moved forward slowly, ran into foreseen and unforeseen problems, and even had to cope with a certain incompatibility between the proposals and attitudes of Canadian consultants and those of the Brazilian personnel (although,

59. Silva Jr., n. 13. 
in concrete terms, the most damaging incompatibility was between an electronic system from the Canadian consultants and SUS systems).

It is hard to say how this process would have developed had it not been for the brusque intervention called the first «intensification phase». At its own pace, the Viva Mulher pilot project was in the process of identifying and implementing methods that would lay the technical foundations of a future program, when there emerged on the scene a political demand for a nationwide campaign - an opportunity whose potential contribution, in principle, only the Ministry of Health seemed to have considered.

Curiously enough, a message from the head of INCA entitled «Four Years of the Viva Mulher Program» («Quatro Anos de Programa Viva Mulher») - part of an assessment published in $2002^{60}$ - ignored the institute's own pilot project and painted the program as wholly planned, its successive phases all intentionally laid out, in a way the facts do not seem to support.

Despite the technical and political fallout occasioned by this intervention in a process until then led by the INCA, this article has pointed some positives outcomes. After all, in the context of drafting public policy, highlighting the nonexistence, insufficiency, or inefficaciousness of screening procedures can in itself be considered a contribution to the process.

When the INCA resumed the management of the program, it moved to strengthen its relations with state health departments in hopes of forming an integrated national network, grounded in a geopolitical management core that could sustain a cervical cancer control program and its various phases of execution.

The program's guiding axis shifted progressively from emphasis on early detection to the concept of «lines of care», within the broader context of the Oncological Care Network, covering all levels of complexity: primary, secondary and tertiary healthcare service, health promotion, prevention, diagnosis, treatment, rehabilitation, and palliative care. Viva Mulher became a permanent program, currently targeting a population of women aged between 25 and 64. Its main focus is the provision of routine exams and the improvement of the Oncological Care Network by providing states with technical assistance, modernizing Siscolo in technological terms, monitoring indicators, and establishing agreements with health managers. 
From a historical perspective, this initial analysis of Viva Mulher is meant to contribute to a debate on health action, especially the study of cervical cancer control initiatives in Brazil, as well as to the more recent understanding of cancer as a public health problem in this country. 